\title{
Gefitinib enhances oxaliplatin-induced apoptosis mediated by Src and PKC-modulated gap junction function
}

\author{
JIAN-FENG WU ${ }^{1 *}$, JIE JI $^{1 *}$, SHU-YING DONG ${ }^{1}$, BEI-BEI LI ${ }^{1}$, MEI-LING YU ${ }^{1}$, \\ DAN-DAN WU ${ }^{1}$, LIANG TAO ${ }^{2}$ and XU-HUI TONG ${ }^{1}$ \\ ${ }^{1}$ Faculty of Pharmacy, Bengbu Medical College, Bengbu, Anhui 233030; ${ }^{2}$ Department of Pharmacology, \\ Zhongshan School of Medicine, Sun Yat-Sen University, Guangzhou, Guangdong 510080, P.R. China
}

Received April 19, 2016; Accepted May 31, 2016

DOI: $10.3892 / o r .2016 .5156$

\begin{abstract}
Chemotherapeutic drug-induced apoptosis is enhanced by gap junction intercellular communication (GJIC) in a variety of tumor cells. Oxaliplatin and gefitinib are the most widely used chemotherapeutic drugs. However, the synergistic influence remains unknown in testicular cancer chemotherapy. The aim of the present study was to investigate the apoptosis induced by oxaliplatin combined with gefitinib and the potential mechanisms in I-10 testicular cancer cells. The results showed that gefitinib significantly enhanced oxaliplatin-induced apoptosis. Furthermore, the ratio of Bcl-2/Bax and the cleavage of caspase- 3 and -9 were increased by gefitinib during oxaliplatin-induced apoptosis. The oxaliplatin-induced apoptosis was enhanced through the upregulation of gap junction (GJ) channels composed of connexin $43(\mathrm{Cx} 43)$ by gefitinib. The mechanism of GJIC enhancement involved the suppression by gefitinib of the expression levels of Src and PKC, which phosphorylate $\mathrm{Cx} 43$ and reduce GJIC. PP2 (Src inhibitor) and GF109203X (PKC inhibitor) also enhanced GJIC function. Our findings demonstrated that gefitinib enhanced oxaliplatin-induced apoptosis in I-10 cells and gefitinib upregulated the GJIC by inhibiting Src and PKC-modulated Cx43 phosphorylation.
\end{abstract}

\section{Introduction}

Gap junctions (GJs) are intercellular channels which allow the passage of small molecules to diffuse (secondary messengers, metabolites and ions) between the cytoplasm of adjacent cells. GJ channels are comprised of membrane-integrated proteins called connexins. Twenty-one members of the connexin protein family have been reported in the human and 20 in

Correspondence to: Dr Xu-Hui Tong, Faculty of Pharmacy, Bengbu Medical College, 2600 Donghai Road, Bengbu, Anhui 233030, P.R. China

E-mail: bbmctxh@126.com

*Contributed equally

Key words: oxaliplatin, gefitinib, gap junction, apoptosis, testis the mouse. Two hexameric oligomers formed by connexins constitute a single GJ channel (1-3). Gap junction intercellular communication (GJIC) plays a vital role in physiological and pathological processes, including cell growth, differentiation, homeostasis and inflammatory responses (4-7). Moreover, GJIC enhances chemotherapeutic drug-induced apoptosis, such as oxaliplatin $(8,9)$, vinblastine (10) and doxorubicin (11). Inhibition of GJIC (channel closure) is related to kinasemodulated connexin phosphorylation, and Src and PKC are involved in connexin 43 (Cx43) phosphorylation (p-Cx43) (12).

Platinum-based drugs are the most widely used chemotherapeutic agents in cancer treatment. Oxaliplatin (OHP), a third-generation platinum-based compound, is approved for use in colon, non-small cell lung cancer (NSCLC) and pancreatic cancer $(13,14)$. Unfortunately, neurotoxicity $(15,16)$ and drug resistance (17-20) limit the clinical use of oxaliplatin. Hence, it is urgent to enhance the anticancer effect of oxaliplatin and decrease off-target toxicity.

Gefitinib, a selective epidermal growth factor receptor (EGFR) tyrosine kinase inhibitor, was first approved for clinical use for the treatment of NSCLC (21). However, patients who develop an acquired resistance to gefitinib may subsequently become refractory (22-24) and skin toxic effects occur (25). Dose-escalation of gefitinib does not improve progression-free survival and overall survival (26). Furthermore, activation of EGFR may increase Src and PKC-modulated Cx43 phosphorylation, consequently inhibiting GJIC (12).

Recent studies have reported that gefitinib may enhance the anticancer effect of oxaliplatin in metastatic colorectal cancer (27) and NSCLC (28). Nevertheless, the potential mechanisms of the enhanced antitumor efficacy remain to be elucidated. Our previous study showed that gefitinib induced apoptosis via the mitochondrial pathway in I-10 testicular cancer cells (29). In the present study, we aimed to investigate the apoptosis induced by oxaliplatin combined with gefitinib, and to reveal the potential mechanisms of GJIC modulated by gefitinib in I-10 cells.

\section{Materials and methods}

Cell lines and cell culture. The testicular cancer cell line (I-10) was purchased from the American Type Culture Collection (ATCC; Manassas, VA, USA). The cells were maintained in 
Ham's F-12 nutrient mixture (F-12) with $2.5 \%$ fetal bovine serum (FBS), 15\% horse serum (all from Gibco, Grand Island, NY, USA), $100 \mathrm{U} / \mathrm{ml}$ penicillin and $100 \mathrm{U} / \mathrm{ml}$ streptomycin in a humidified incubator supplemented with $5 \% \mathrm{CO}_{2}$ at $37^{\circ} \mathrm{C}$.

3-(4,5-Dimethylthiazol-2-yl)-2,5-diphenyltetrazolium bromide (MTT) assay. Cells $\left(5 \times 10^{4}\right)$ were seeded in 96-well plates and cultured for $24 \mathrm{~h}$ (70-80\% confluency). Cells were subjected to a range of oxaliplatin (Sigma-Aldrich, St. Louis, MO, USA) concentration $(0,5,10,20,40,80,160$ and $320 \mu \mathrm{M})$ for $24 \mathrm{~h}$. Where indicated, $1 \mu \mathrm{M}$ gefitinib (Sigma-Aldrich) was added $24 \mathrm{~h}$ before oxaliplatin stimuli. Oxaliplatin was freshly dissolved in phosphate-buffered solution (PBS) at stock solutions. Gefitinib stock solutions were prepared in dimethyl sulfoxide (DMSO) (Sigma-Aldrich). Cells exposure to oxaliplatin and gefitinib were performed in the dark. The cells were treated with fresh medium with $20 \mu \mathrm{l}$ of MTT $(5 \mathrm{mg} / \mathrm{ml}$ ) (Sigma-Aldrich) solution for $4 \mathrm{~h}$. Then, the medium was removed and the formed dark blue formazan was dissolved in $150 \mu \mathrm{l}$ DMSO. The absorbance [optical density, (OD)] at $570 \mathrm{~nm}$ was measured by a microplate reader (Bio-Rad Laboratories, Hercules, CA, USA).

Flow cytometry. Cells $\left(1 \times 10^{5}\right)$ were seeded in 12-well plates and cultured for $24 \mathrm{~h}$ (70-80\% confluency). The cells were pretreated with $1 \mu \mathrm{M}$ gefitinib for $24 \mathrm{~h}$ and then exposed to $40 \mu \mathrm{M}$ oxaliplatin for $8 \mathrm{~h}$. The samples were collected, rinsed twice with cold PBS, suspended in binding buffer and incubated with $5 \mu 1$ Annexin V-FITC and $5 \mu 1$ propidium iodide (PI) (FITC/Annexin V apoptosis detection kit; BD Biosciences, New York, NY, USA) at room temperature in the dark for $15 \mathrm{~min}$. The samples were immediately analyzed by Auccri C6 flow cytometer (BD Biosciences). Early-stage apoptotic cells were shown in the lower right quadrant $\left(\right.$ Annexin $\left.\mathrm{V}^{+} / \mathrm{PI}\right)$.

Hoechst 33258 staining assay. Cells $\left(1 \times 10^{5}\right)$ were seeded in 12 -well plates and cultured for $24 \mathrm{~h}$ (70-80\% confluency). The cells were pretreated with $1 \mu \mathrm{M}$ gefitinib for $24 \mathrm{~h}$ and then exposed to $40 \mu \mathrm{M}$ oxaliplatin for $16 \mathrm{~h}$. Then, the medium was removed and the cells were fixed with $4 \%$ paraformaldehyde solution for $30 \mathrm{~min}$. Fixed cells were washed twice with PBS and stained with $500 \mu \mathrm{l}$ Hoechst $33258(10 \mu \mathrm{g} / \mathrm{ml})$ (Sigma-Aldrich) for $30 \mathrm{~min}$ in the dark. The late-stage apoptotic cells (shrunken nuclei, chromatin condensation and apoptotic body) were photographed with fluorescence microscopy (Olympus IX73; Olympus, Tokyo, Japan) and counted at a magnification of $\mathrm{x} 200$.

Western blot analysis. Cells were washed three times with cold PBS and harvested using lysis buffer (Beyotime, Shanghai, China). Cell lysate was centrifuged and protein concentration was determined using the BCA method. Protein samples were analyzed by $10 \%$ sodium dodecyl sulfate-polyacrylamide electrophoresis (SDS-PAGE) gel and electrophoretically transferred onto polyvinylidene difluoride (PVDF) membranes (0.45 $\mu \mathrm{m}$; Millipore, Billerica, MA, USA) followed by immunoblotting. Rabbit antibodies against Bcl-2 $(1: 1,000)$ (12789-1-AP), Bax (1:1,000) (50599-2-Ig), Src $(1: 1,000)$ (11097-1-AP), PKC (1:1,000) (12919-1-AP) (ProteinTech, Chicago, IL, USA), caspase-3 (1:1,000) (ab90437), caspase-9

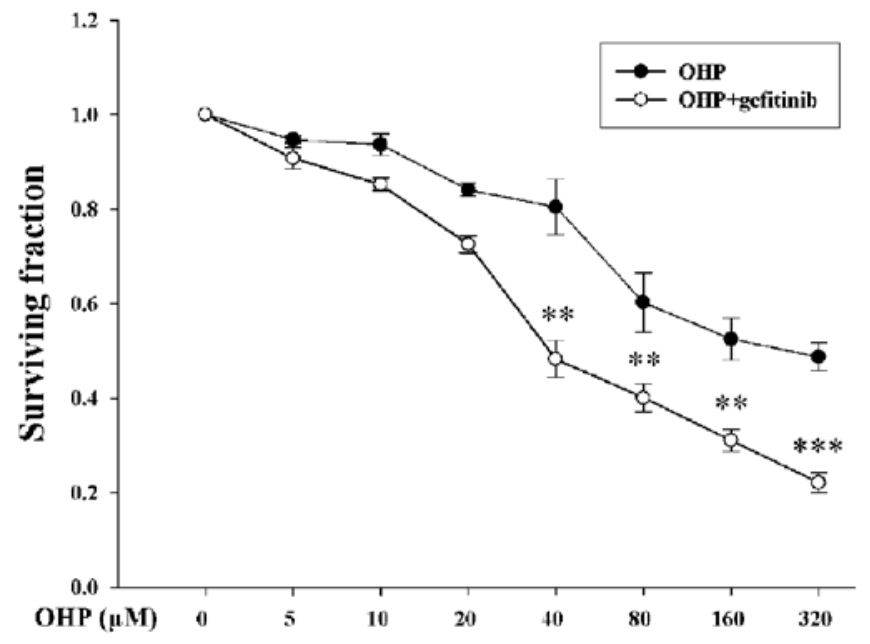

Figure 1. Cell surviving fraction was measured by the MTT assay. I-10 cells were pretreated with or without $1 \mu \mathrm{M}$ gefitinib (no toxicity on I-10 cells) for $24 \mathrm{~h}$, followed by exposure to $0-320 \mu \mathrm{M}$ oxaliplatin for $24 \mathrm{~h}$. Data indicate mean \pm SD for $\mathrm{n}=5$ wells from three experiments; ${ }^{* *} \mathrm{P}<0.01,{ }^{* * *} \mathrm{P}<0.001$, significantly different from the oxaliplatin (OHP) group.

(1:200) (ab25758), Cx43 (1:8,000) (ab11370), p-Cx43 (1:1,000) (ab30559) (Abcam, Cambridge, MA, USA), and mouse antibody against GAPDH $(1: 5,000)$ (60004-1-lg) (ProteinTech) were used. Immunopositive bands were visualized by Immobilon Western $^{\mathrm{TM}}$ Chemiluminescent HRP Substrate (Millipore) and quantified with ImageJ software (National Institutes of Health, Bethesda, MD, USA).

Immunofluorescence assay. Cells $\left(1 \times 10^{5}\right)$ plated in 12-well plates were cultured for $24 \mathrm{~h}$ to reach $70-80 \%$ confluency, and were treated with $1 \mu \mathrm{M}$ gefitinib for $24 \mathrm{~h} ; 8 \mu \mathrm{M}$ PP2 for $8 \mathrm{~h} ; 10 \mu \mathrm{M}$ GF109203X for $10 \mathrm{~h}$. The cells were fixed in $4 \%$ paraformaldehyde for $15 \mathrm{~min}$. Fixed cells were washed twice with PBS and incubated with 5\% bovine serum albumin for $2 \mathrm{~h}$. Cells were incubated with rabbit antibody against $\mathrm{Cx} 43$ $(1: 1,000)$ at $4^{\circ} \mathrm{C}$ overnight and with FITC-anti-rabbit IgG (1:100) (Sigma-Aldrich) at $37^{\circ} \mathrm{C}$ for $2 \mathrm{~h}$ in the dark. Then, the cells were stained with $5 \mu \mathrm{g} / \mathrm{ml}$ 4',6-diamidino-2-phenylindole (DAPI) for $5 \mathrm{~min}$ in the dark. The cells were captured using fluorescence microscopy (Olympus) at a magnification of x200.

'Parachute' dye-coupling assay. Functional GJIC was performed as previously described (30). Cells $\left(1 \times 10^{5}\right)$ plated in 12-well dishes were cultured for $24 \mathrm{~h}$ to reach $70-80 \%$ confluency, and were treated with gefitinib, PP2 or GF109203X as mentioned above. Donor cells from one well were incubated with $10 \mu \mathrm{g} / \mathrm{ml}$ calcein AM and $5 \mu \mathrm{g} / \mathrm{ml} \mathrm{CM}$-DiI (ProteinTech) in growth medium at $37^{\circ} \mathrm{C}$ for $30 \mathrm{~min}$. Calcein-AM is intracellularly converted into the GJ-permeable dye calcein and CM-DiI is a membrane dye that does not spread to coupled cells. Then, the donor cells were trypsinized and seeded onto the receiver cells at a 1:200 donor/receiver ratio. Cells were allowed to attach to the monolayer of the receiver cells and form GJs for $4 \mathrm{~h}$ at $37^{\circ} \mathrm{C}$ and photographed with fluorescence microscopy (Olympus). The average number of receiver cells containing dye per donor cell was counted at a magnification of x200 as a measure of the degree of GJIC. 
A

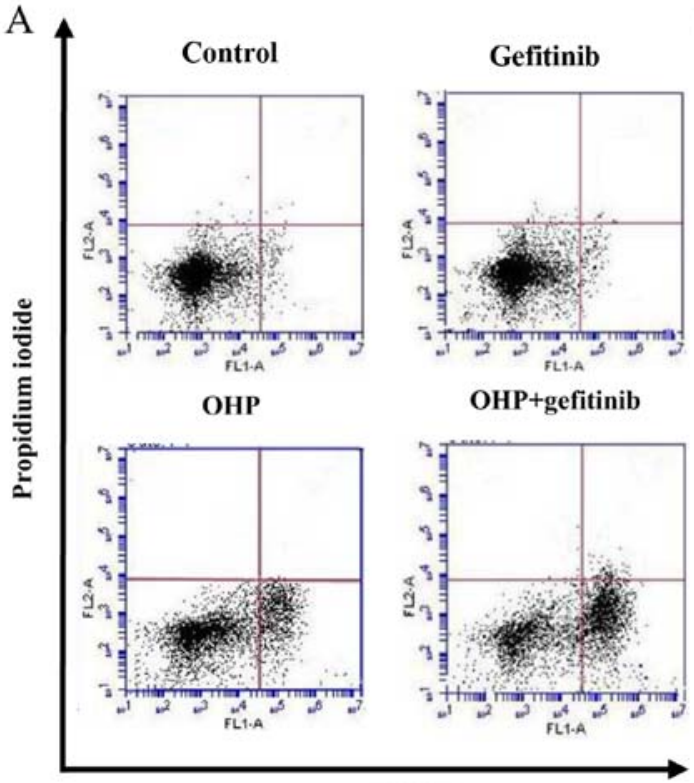

Annexin V FITC

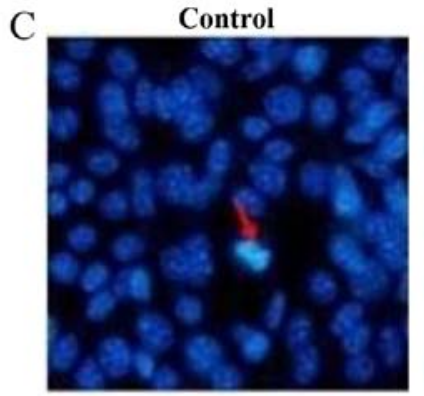

OHP

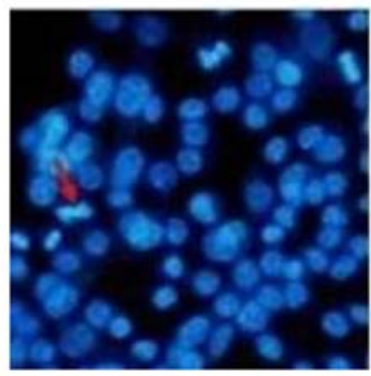

$\mathrm{D}$

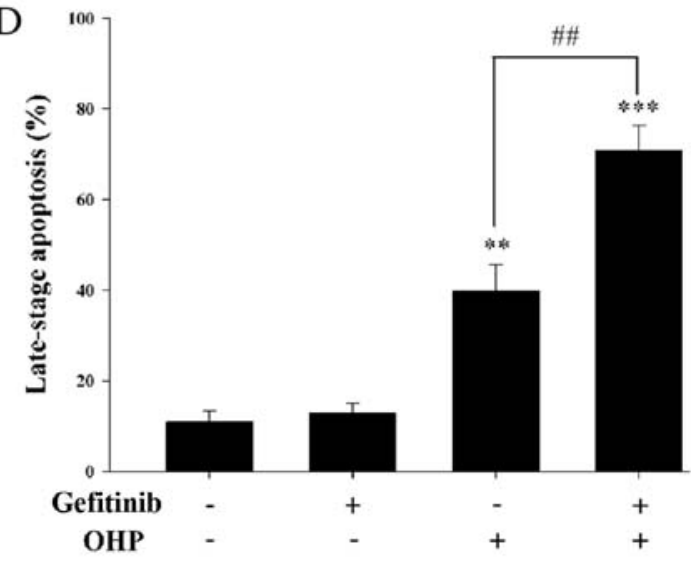

Figure 2. (A) Early-stage apoptosis induced by oxaliplatin (OHP) combined with gefitinib was assessed by the Annexin V/PI staining method using flow cytometry. (B) Relative quantity of early-stage apoptosis ratio. (C) Late-stage apoptosis induced by OHP combined with gefitinib was shown by Hoechst 33258 staining assay (magnification, $\mathrm{x} 200$ ). (D) Relative quantity of late-stage apoptosis ratio. Data indicate mean \pm SD for $\mathrm{n}=3$ wells from three experiments; ${ }^{* *} \mathrm{P}<0.01,{ }^{* * *} \mathrm{P}<0.001$, significantly different from the control group; ${ }^{\# \#} \mathrm{P}<0.01$, significantly different from the OHP group.

Statistical analysis. All of the experiments had a minimum of three determinations. Data are presented as mean and standard deviation (SD). Statistical analyses between two groups were performed by Student's t-test using SPSS 16.0 (SPSS, Inc., Chicago, IL, USA). $\mathrm{P}<0.05$ was considered statistically significant.

\section{Results}

Gefitinib enhances oxaliplatin-induced apoptosis. Cell survival was assessed by MTT assay. I-10 cells were pretreated with or without $1 \mu \mathrm{M}$ gefitinib (no toxicity on I-10 cells) for $24 \mathrm{~h}$, followed by exposure to $0-320 \mu \mathrm{M}$ oxaliplatin for $24 \mathrm{~h}$. After treatment with 40,80, 160 and $320 \mu \mathrm{M}$ oxaliplatin combined with and without gefitinib, cell surviving fractions were $0.48 \pm 0.04,0.40 \pm 0.29,0.31 \pm 0.02,0.22 \pm 0.02$ and $0.80 \pm 0.06$, $0.60 \pm 0.06,0.53 \pm 0.04,0.49 \pm 0.03$, respectively (Fig. 1). Cell survival was significantly decreased in the presence of gefitinib $(\mathrm{P}<0.05)$.
Chemotherapeutic drugs show antitumor effects by increasing the apoptosis of cancer cells which include earlystage and late-stage apoptosis. Annexin V/PI staining assay was used to assess the early-stage apoptosis. As shown in Fig. 2A, early-stage apoptosis was induced following treatment with $40 \mu \mathrm{M}$ oxaliplatin for $8 \mathrm{~h}$ with $1 \mu \mathrm{M}$ gefitinib pretreatment for $24 \mathrm{~h}$. As shown in Fig. 2B, the rate of early-stage apoptosis was $60.47 \pm 4.80 \%$ in the presence of gefitinib and $31.23 \pm 3.47 \%$ in the absence of gefitinib. As shown in Fig. 2C, late-stage apoptosis was induced by $40 \mu \mathrm{M}$ oxaliplatin for $16 \mathrm{~h}$ with $1 \mu \mathrm{M}$ gefitinib pretreatment for $24 \mathrm{~h}$ as assessed by Hoechst 33258 staining assay. As shown in Fig. 2D, the ratio of late-stage apoptosis was $70.69 \pm 5.58 \%$ in the presence of gefitinib and $39.80 \pm 5.81 \%$ in the absence of gefitinib. Both the early- and late-stage apoptosis rates were increased by $\sim 40 \%$ when cells were pretreated with gefitinib $(\mathrm{P}<0.05)$.

Obviously, these results demonstrated that oxaliplatin-induced apoptosis was enhanced by gefitinib in the I-10 cells. 

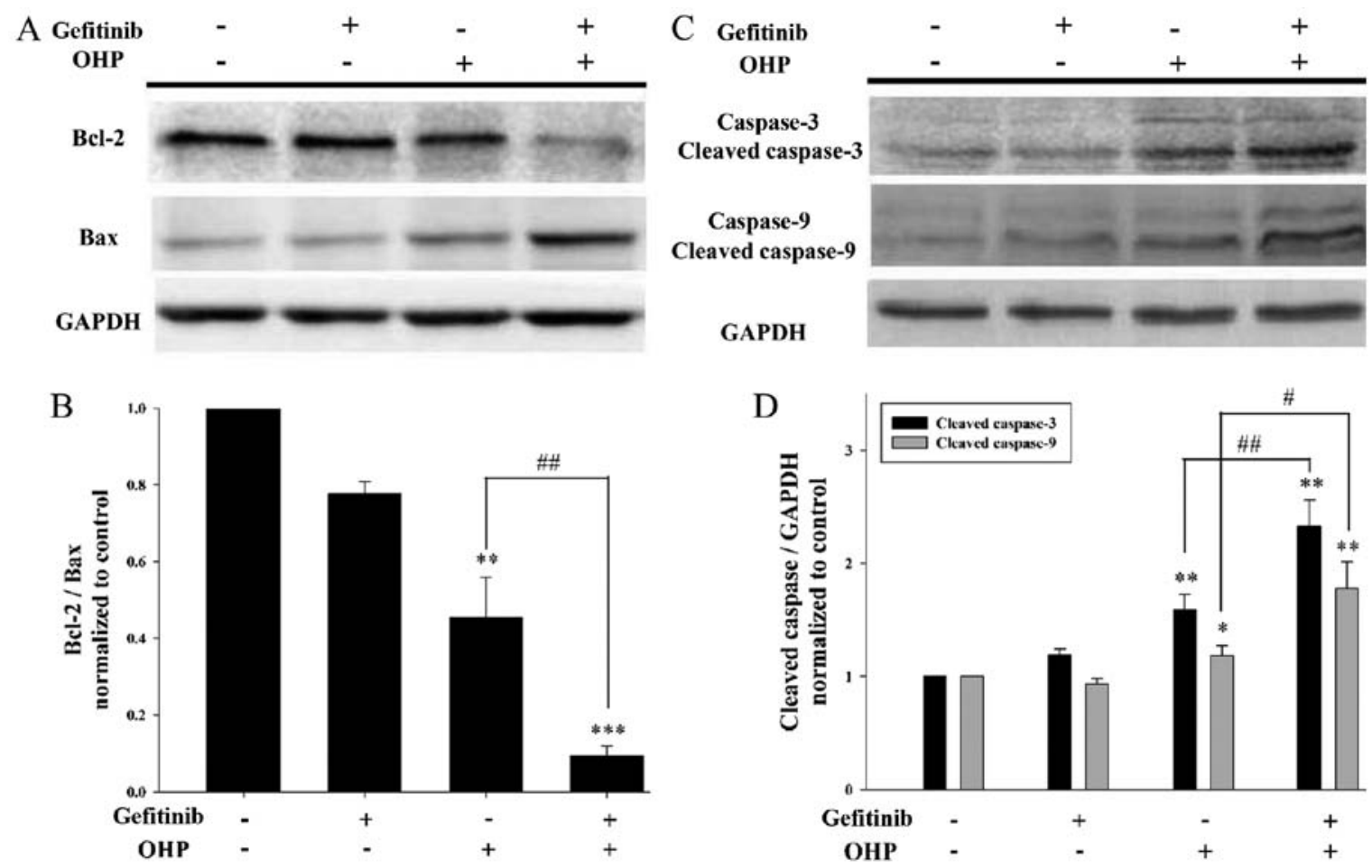

Figure 3. Effects of gefitinib on oxaliplatin (OHP)-induced apoptosis-related protein expression were detected by western blotting. (A) Representative bands of Bcl-2 and Bax. (B) Relative quantity of Bcl-2 and Bax. (C) Representative bands of cleaved caspase-3 and -9. (D) Relative quantity of cleaved caspase-3 and -9. Experiments were repeated 3-5 times with data representing mean $\pm \mathrm{SD} ;{ }^{*} \mathrm{P}<0.05,{ }^{* *} \mathrm{P}<0.01,{ }^{* * * *} \mathrm{P}<0.001$, significantly different from the control group; ${ }^{\sharp} \mathrm{P}<0.05$, ${ }^{\# \#} \mathrm{P}<0.01$, significantly different from the OHP group.

Gefitinib decreases the ratio of Bcl-2/Bax and increases the cleavage of caspase-3 and -9 during oxaliplatin-induced apoptosis. Bcl-2, Bax and caspase-3 and -9 are vital participators in the mitochondrial apoptosis pathway, which is involved in apoptosis induced by platinum-based drugs. Therefore, western blotting was used to assess the expression levels of Bcl-2, Bax and caspase- 3 and -9 after I-10 cells were exposed to $40 \mu \mathrm{M}$ oxaliplatin for $12 \mathrm{~h}$ with $1 \mu \mathrm{M}$ gefitinib pretreatment for $24 \mathrm{~h}$ (Fig. 3). As shown in Fig. 3A, the expression of Bcl-2 (protects against apoptosis) was decreased in the presence of gefitinib, and contrarily the expression of Bax (promotes apoptosis) was increased. Thus, the ratio of $\mathrm{Bcl}-2 / \mathrm{Bax}$ was significantly decreased by gefitinib $(\mathrm{P}<0.05)$ (Fig. 3B). In addition, as shown in Fig. $3 \mathrm{C}$ and $\mathrm{D}$, the cleavage of caspase- 3 and -9 was greatly increased in the presence of gefitinib $(\mathrm{P}<0.05)$. These results suggest that gefitinib modulates apoptosis-related proteins (Bcl-2, Bax and caspase-3 and -9) during oxaliplatin-induced apoptosis in I-10 cells.

Gefitinib inhibits Cx43 phosphorylation and enhances GJIC. Cx43 is the most abundant connexin in testicular tissue (31). Our previous study demonstrated that GJ channels composed of $\mathrm{Cx} 43$ decreased the ratio of $\mathrm{Bcl}-2 / \mathrm{Bax}$ and increased the cleavage of caspase- 3 and -9 during oxaliplatin-induced apoptosis in I-10 cells (8). To determine whether gefitinib could affect the function of GJIC in I-10 cells, western blotting was used to assess the expression levels of $\mathrm{Cx} 43$ and p-Cx43 (Fig. 4A). As shown in Fig. 4B, gefitinib increased the expression of $\mathrm{Cx} 43$ (functional GJ), and contrarily decreased the expression of $\mathrm{p}-\mathrm{Cx} 43$ (non-effective GJ). Moreover, $\mathrm{Cx} 43$ protein expression on the membrane was assessed by immu- nofluorescence assay. As shown in Fig. 4C, gefitinib increased the expression of $\mathrm{Cx} 43$ on the membrane, which was consistent with the western blotting results. Parachute assay was used to measure the effect of gefitinib on GJIC (Fig. 4D). As shown in Fig. 4E, gefitinib markedly increased the degree of dye spread which represents GJIC function. These results indicate that the function of GJIC in I-10 cells was enhanced by the inhibition of $\mathrm{Cx} 43$ phosphorylation by gefitinib.

Gefitinib reduces the expression levels of Src and PKC. Src and PKC inhibit GJIC by increasing Cx43 phosphorylation (12). We aimed to asertain whether there is a relationship between GJIC function enhanced by gefitinib and Src and PKC. Western blotting was used to detect the effects of gefitinib on Src and PKC expression levels. As shown in Fig. 5, the expression levels of Src and PKC were obviously decreased by gefitinib.

To further verify the relationship between GJIC and the expression levels of Src and PKC, PP2 (Src inhibitor) and GF109203X (PKC inhibitor) were used to treat the I-10 cells. Due to the time restriction concerning PP2 and GF109203X, cells were treated with $8 \mu \mathrm{M}$ PP2 and $10 \mu \mathrm{M}$ GF109203X for $0,6,8,10,12$ and $24 \mathrm{~h}$. As shown in Fig. 6A and B, the optimum time points for the inhibition of Src and PKC were 8 and $10 \mathrm{~h}$. Thus, I-10 cells were incubated with PP2 for $8 \mathrm{~h}$; GF109203X for $10 \mathrm{~h}$ in the next experiments. Then, the expression of $\mathrm{p}-\mathrm{Cx} 43$ was detected by western blotting (Fig. 6C). PP2 and GF109203X significantly decreased p-Cx43 expression (Fig. 6D). In contrast, the expression of $\mathrm{Cx} 43$ on the membrane was largely increased by PP2 and GF109203X (Fig. 6E). Moreover, the parachute assay was used to detect the effects of PP2 and GF109203X on 

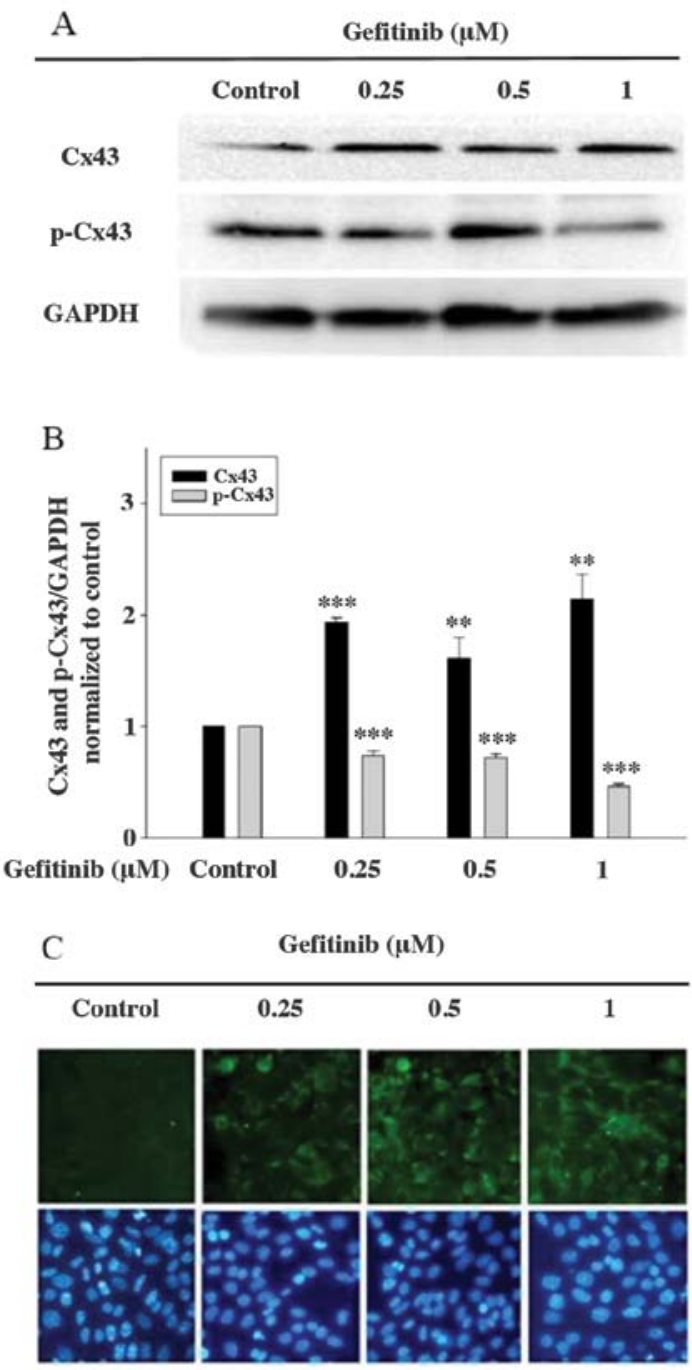

D Gefitinib $(\mu M)$
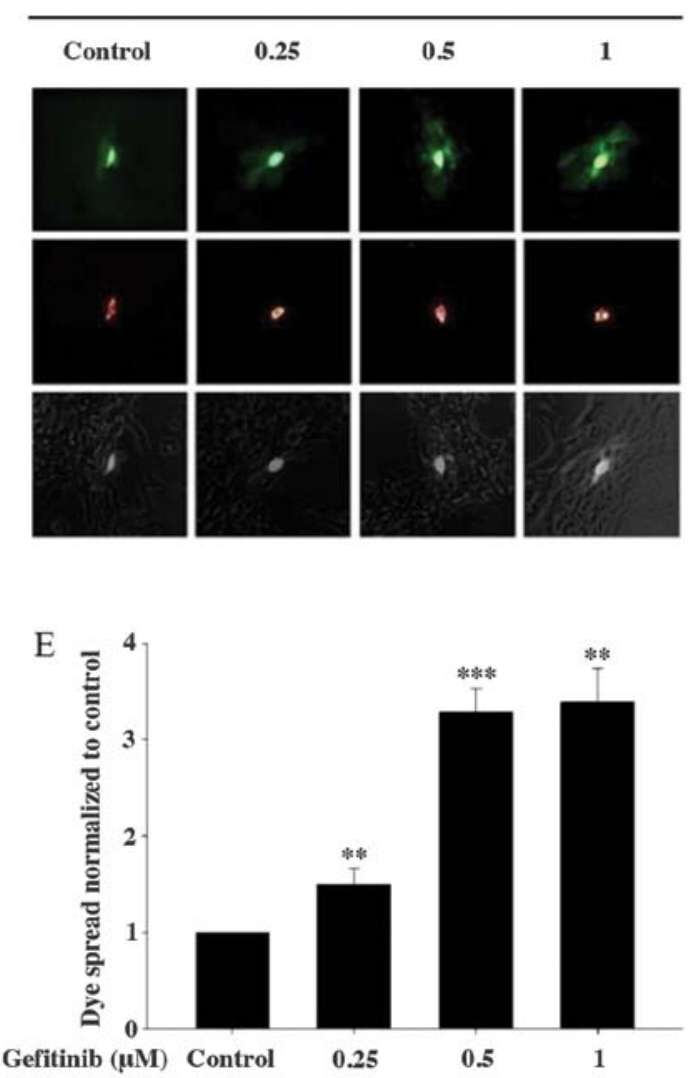

Figure 4. Effects of gefitinib on Cx43 phosphorylation and gap junction intercellular communication (GJIC). (A) The expression levels of Cx43 and p-Cx43 were measured by western blotting. (B) Relative quantity of $\mathrm{Cx} 43$ and $\mathrm{p}-\mathrm{Cx} 43$ expression. Data indicate mean \pm SD from three experiments; ${ }^{* *} \mathrm{P}<0.01$, ${ }^{* * *} \mathrm{P}<0.001$, significantly different from the control group; ${ }^{\# \#} \mathrm{P}<0.01$, significantly different from the OHP group. (C) Immunofluorescence assay was used to detect the expression of $\mathrm{Cx} 43$ on the membrane (magnification, x200). (D) GJIC was measured by the parachute assay (magnification, x200). (E) Relative quantity of dye spread. Data indicate mean $\pm \mathrm{SD}$ for $\mathrm{n}=3$ wells from three experiments; ${ }^{* *} \mathrm{P}<0.01,{ }^{* * *} \mathrm{P}<0.001$, significantly different from the control group.
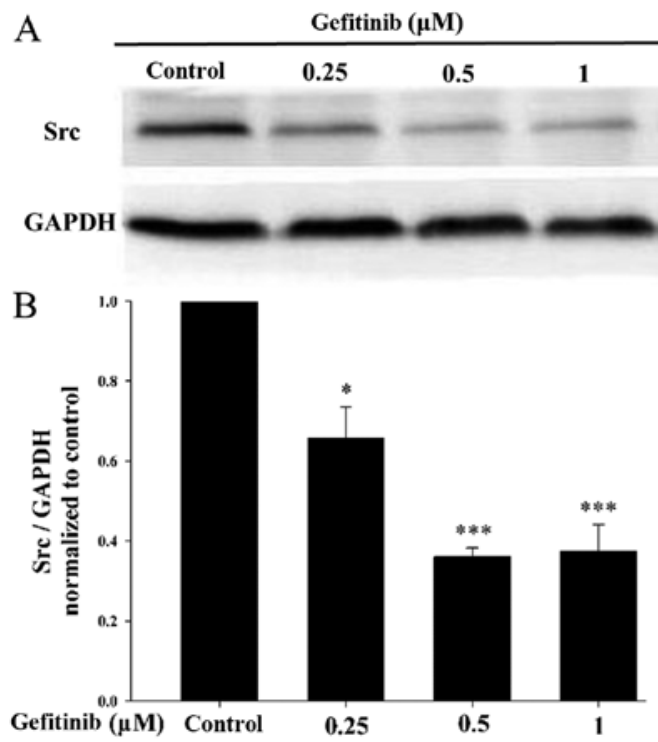

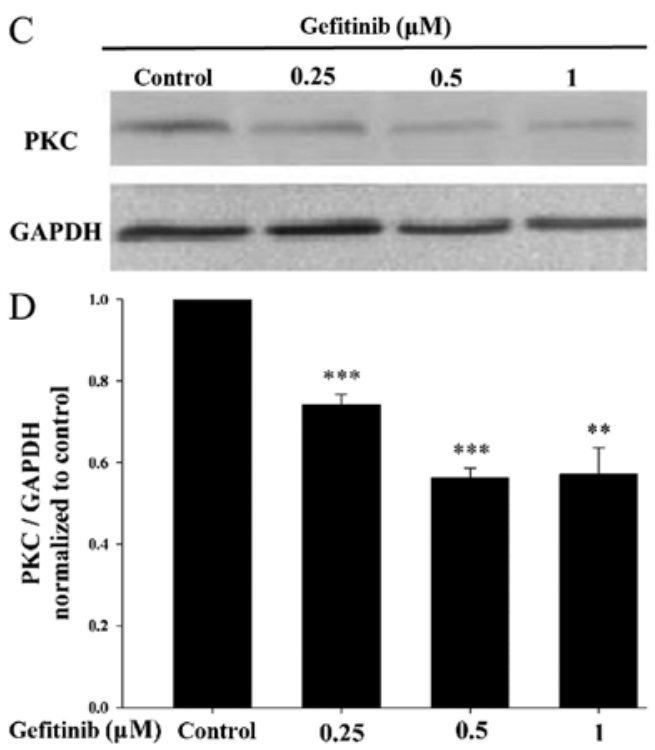

$\begin{array}{llll}\text { Gefitinib }(\mu \mathrm{M}) \text { Control } & 0.25 & 0.5 & 1\end{array}$

Figure 5. Effects of gefitinib on the expression levels of Src and PKC are showed by western blotting. (A) Representative bands of Src. (B) Relative quantity of Src. (C) Representative bands of PKC. (D) Relative quantity of PKC. Experiments were repeated 3-4 times with data showing mean \pm SD; ${ }^{*} \mathrm{P}<0.05,{ }^{* * *} \mathrm{P}<0.01$, ${ }^{* * *} \mathrm{P}<0.001$, significantly different from the control group. 


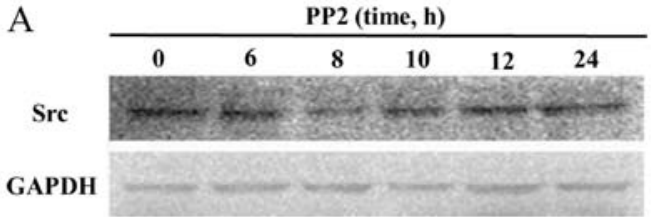

B

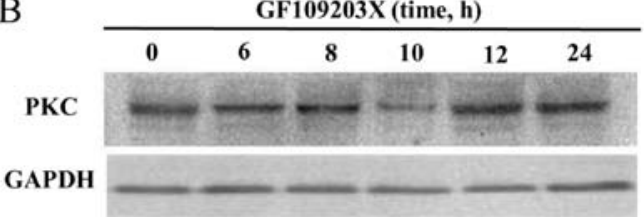

$\mathrm{C}$

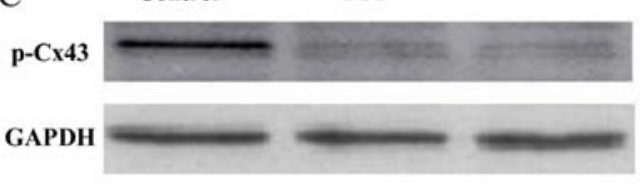

$\mathrm{D}$

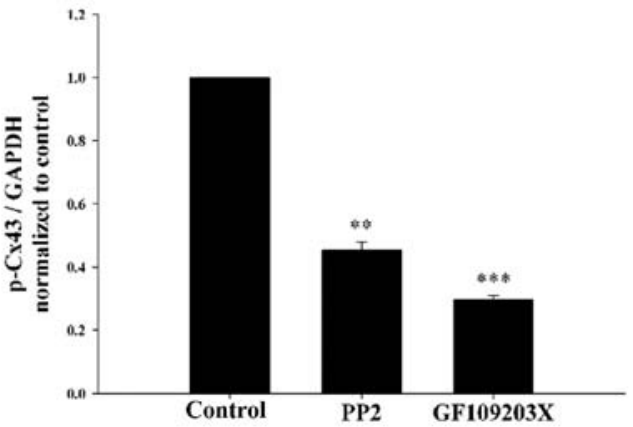

E

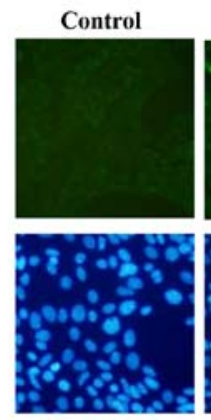

$\mathrm{F}$
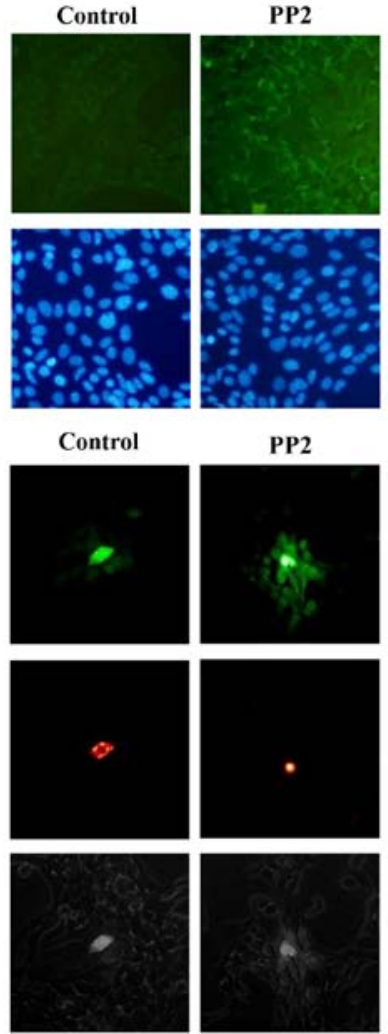

GF109203X
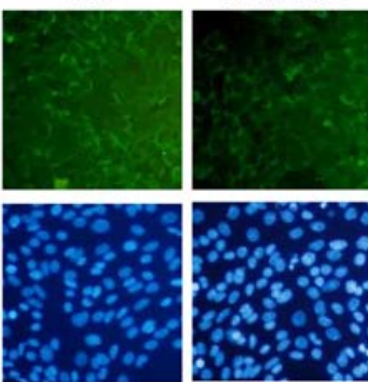

PP2

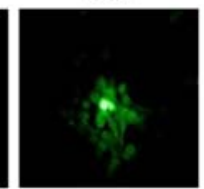

GF109203X
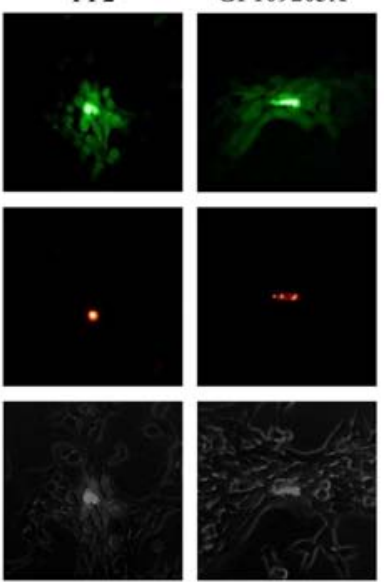

G

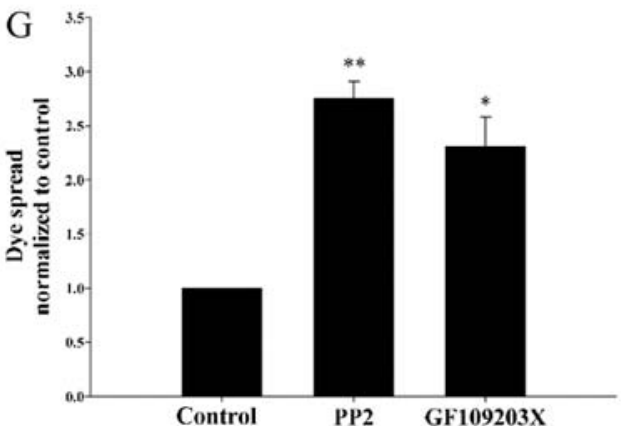

Figure 6. Effects of PP2 and GF109203X on Cx43 expression and gap junction intercellular communication (GJIC). (A) Eight hours was the optimum time point for PP2 to reduce Scr expression. (B) Ten hours was the optimum time point for GF109203X to reduce PKC expression. (C) The expression of p-Cx43 was measured by western blotting. (D) Relative quantity of $\mathrm{p}-\mathrm{Cx} 43 ;{ }^{* *} \mathrm{P}<0.01,{ }^{* * * *} \mathrm{P}<0.001$, significantly different from the control group. (E) Immunofluorescence assay was used to detect the expression of Cx43 on membrane (magnification, x200). (F) GJIC was measured by parachute assay (magnification, $\mathrm{x} 200$ ). (G) Relative quantity of dye spread. Data indicate mean $\pm \mathrm{SD}$ for $\mathrm{n}=4$ wells from three experiments; ${ }^{*} \mathrm{P}<0.05,{ }^{* *} \mathrm{P}<0.01$, significantly different from the control group.

GJIC (Fig. 6F). As shown in Fig. 6G, PP2 and GF109203X significantly enhanced GJIC. These results further determined that gefitinib enhanced GJIC (Fig. 4) by inhibiting Src- and PKC-induced Cx43 phosphorylation.

\section{Discussion}

The results of the present study showed for the first time that gefitinib can enhance oxaliplatin-induced apoptosis in I-10 testicular cancer cells as assessed by cell survival, apoptosis, Bcl-2/Bax (apoptosis regulator) and activation of caspase-3 and -9. Moreover, we demonstrated that gefitinib enhanced gap junction intercellular communication (GJIC) by inhibiting the expression levels of Src and PKC which act to increase $\mathrm{Cx} 43$ phosphorylation and decrease GJIC. Therefore, the synergistic influence of gefitinib on oxaliplatin anti-neoplastic effect is attributable to the upregulation of gap junction (GJ) channels composed of Cx43.

Oxaliplatin is an essential chemotherapeutic drug in cancer treatment. The primary mechanism of oxaliplatin-induced apoptosis is that reactive platinum molecules react with DNA to form inter-strand and intra-strand DNA adducts that arrest transcription, DNA replication and repair. As DNA is the essential genetic material in organisms, DNA-damage results in apoptosis $(13,32,33)$. Additionally, oxaliplatin-induced apoptosis is influenced by a variety of factors, such as p53, autophagy, Bcl-2 family and receptor interacting protein kinase 1 (RIP1). Shi et al (34) reported that oxaliplatininduced colorectal cancer cell apoptosis was enhanced by apoptosis stimulated protein of p53-2 (ASPP2) via inhibition of autophagy. Timme et al (35) showed that increased protein levels of Mcl-1 and/or Bcl-xL as well as reduction in Bax and 
Bak activation attenuated oxaliplatin-induced apoptosis in human colon cancer cells. Shan et al (36) indicated that downregulation of RIP1 promoted oxaliplatin-induced apoptosis in tongue squamous cell carcinoma.

Recent studies have reported that gefitinib, one of the EGFR tyrosine kinase (EGFR-TK) inhibitors, shows an antitumor effect in bladder cancer (37) and glioblastoma (38). Gefitinib causes the malfunction of EGFR-TK which leads to obstruction of mitogen-activated protein kinase (MAPK) and the phosphatidylinositol-3-kinase (PI3K)/AKT pathways. As a result, cancer cell proliferation is decreased while apoptosis is increased $(39,40)$. In the present study, we showed that oxaliplatin-induced apoptosis is enhanced by gefitinib in I-10 cells. Our previous studies demonstrated that the mitochondrial pathway is involved in oxaliplatin-induced apoptosis (8). To explore the mechanisms, we first determined the expression of apoptosis-related proteins. The Bcl-2/Bax signaling pathway and caspase- 3 and -9 are crucial regulators of apoptosis. Long et al (41) reported that the expression of $\mathrm{Bcl}-2 / \mathrm{Bax}$ is involved in diabetes mellitus-induced testicular damages. Bcl-2, an anti-apoptotic protein in the Bcl-2 protein family, prevents cell apoptosis by interfering with the caspase-3-dependent proteolytic cascade (42). In contrast, Bax is a pro-apoptotic factor which binds to and antagonizes the Bcl-2 protein. In the present study, we showed that gefitinib significantly decreased the ratio of $\mathrm{Bcl}-2 / \mathrm{Bax}$ during oxaliplatin-induced apoptosis in I-10 cells. Caspase protein is downstream of $\mathrm{Bcl}-2 / \mathrm{Bax}$ and caspase activation acts as the most important executor for chemotherapeutic drug-induced apoptosis. In the present study, the cleavage of caspase- 3 and -9 was increased by gefitinib during oxaliplatin-induced apoptosis in I-10 cells. These results suggest that the oxaliplatin-induced apoptosis enhanced by gefitinib is associated with downregulation of Bcl-2/Bax and activation of caspase-3 and -9 .

The cytotoxicity of chemotherapy and radiotherapy is enhanced by GJIC in a variety of tumor cells (43-46). Toxic drug metabolites and apoptotic signals can propagate through GJ channels, so that the toxic effects are amplified. This is called the 'bystander' effect. The candidate signals include the following second messengers such as 1,4,5-trisphosphate $\left(\mathrm{IP}_{3}\right)$ and $\mathrm{Ca}^{2+}$. Eugenin and Berman (47) showed that $\mathrm{IP}_{3}$ and intracellular $\mathrm{Ca}^{2+}$ released from HIV-infected astrocytes transmitted through GJs resulted in bystander apoptosis of neighboring uninfected astrocytes. Decrock et al (48) reported that the cytochrome $c$-induced apoptosis was markedly dependent on the GJ channels permeable to $\mathrm{IP}_{3}$.

Cx43 is the most abundant connexin in testicular tissue. Its life cycle (trafficking, assembly, gating, internalization and degradation) is related to phosphorylation and phosphorylation event leading to the downregulation of GJIC (12). The activation of EGFR contributes to Src activation, which mediates direct phosphorylation of Cx43 (49-52). Furthermore, PKC activated directly by Src mediates the phosphorylation of Cx43, causing decreased GJ assembly and reduced half-life of Cx43 (51,53). As a result, GJIC is inhibited (channel closure) by Src and PKC. In the present study, we showed that gefitinib inhibited Cx43 phosphorylation and enhanced the function of GJIC in I-10 cells. Meanwhile, the expression levels of Src and PKC were decreased by gefitinib. Moreover, PP2 (Src inhibitor) and GF109203X (PKC inhibitor) also enhanced the function of GJIC. Therefore, we attribute the enhanced GJIC to the decreased Src and PKC expression levels induced by gefitinib.

In summary, our results clearly demonstrated that gefitinib enhanced oxaliplatin-induced apoptosis. In addition, gefitinib downregulated the ratio of $\mathrm{Bcl}-2 / \mathrm{Bax}$ and increased cleavage of caspase-3 and -9 during oxaliplatin-induced apoptosis. We attributed these effects to the enhanced GJIC induced by gefitinib through inhibition of the expression levels of Src and PKC. These findings offer a new therapeutic strategy for testicular cancer chemotherapy.

\section{Acknowledgements}

The present study was supported by the National Natural Science Foundation of China (81402930), the Anhui Provincial Natural Science Foundation of the Institution of Higher Education (no. KJ2015A180), the Anhui Province Outstanding Youth Elite Support Program of the Institution of Higher Education (no. gxyqZD2016158), and the Bengbu Medical College Natural Science Foundation (no. BYKY1407ZD).

\section{References}

1. Goodenough DA, Goliger JA and Paul DL: Connexins, connexons, and intercellular communication. Annu Rev Biochem 65: 475-502, 1996.

2. Nielsen MS, Axelsen LN, Sorgen PL, Verma V, Delmar M and Holstein-Rathlou NH: Gap junctions. Compr Physiol 2: 1981-2035, 2012

3. Su V and Lau AF: Connexins: Mechanisms regulating protein levels and intercellular communication. FEBS Lett 588: 1212-1220, 2014

4. Vinken M, Vanhaecke T, Papeleu P, Snykers S, Henkens T and Rogiers V: Connexins and their channels in cell growth and cell death. Cell Signal 18: 592-600, 2006.

5. Stains JP and Civitelli R: Connexins in the skeleton. Semin Cell Dev Biol 50: 31-39, 2016.

6. Plotkin LI and Stains JP: Connexins and pannexins in the skeleton: Gap junctions, hemichannels and more. Cell Mol Life Sci 72: 2853-2867, 2015.

7. Kidder GM and Cyr DG: Roles of connexins in testis development and spermatogenesis. Semin Cell Dev Biol 50: 22-30, 2016.

8. Tong X, Han X, Yu B, Yu M, Jiang G, Ji J and Dong S: Role of gap junction intercellular communication in testicular leydig cell apoptosis induced by oxaliplatin via the mitochondrial pathway. Oncol Rep 33: 207-214, 2015.

9. Yu BB, Dong SY, Yu ML, Jiang GJ, Ji J and Tong XH: Total flavonoids of Litsea coreana enhance the cytotoxicity of oxaliplatin by increasing gap junction intercellular communication. Biol Pharm Bull 37: 1315-1322, 2014.

10. Takano Y, Iwata H, Yano Y, Miyazawa M, Virgona N, Sato H, Ueno $\mathrm{K}$ and Yano T: Up-regulation of connexin 32 gene by 5-aza-2'-deoxycytidine enhances vinblastine-induced cytotoxicity in human renal carcinoma cells via the activation of JNK signalling. Biochem Pharmacol 80: 463-470, 2010.

11. Huang RP, Hossain MZ, Huang R, Gano J, Fan Y and Boynton AL: Connexin 43 (cx43) enhances chemotherapy-induced apoptosis in human glioblastoma cells. Int J Cancer 92: 130-138, 2001.

12. Thévenin AF, Kowal TJ, Fong JT, Kells RM, Fisher CG and Falk MM: Proteins and mechanisms regulating gap-junction assembly, internalization, and degradation. Physiology 28 : 93-116, 2013.

13. Kelland L: The resurgence of platinum-based cancer chemotherapy. Nat Rev Cancer 7: 573-584, 2007.

14. Wheate NJ, Walker S, Craig GE and Oun R: The status of platinum anticancer drugs in the clinic and in clinical trials. Dalton Trans 39: 8113-8127, 2010.

15. Marmiroli P, Cavaletti G, Carozzi V, Riva B, Lim D and Genazzani AA: Calcium-related neurotoxicity of oxaliplatin: Understanding the mechanisms to drive therapy. Curr Med Chem 22: 3682-3694, 2015. 
16. Di Cesare Mannelli L, Tenci B, Zanardelli M, Failli P and Ghelardini C: $\alpha 7$ Nicotinic receptor promotes the neuroprotective functions of astrocytes against oxaliplatin neurotoxicity. Neural Plast 2015: 396908, 2015.

17. Moutinho C, Martinez-Cardús A, Santos C, Navarro-Pérez V, Martínez-Balibrea E, Musulen E, Carmona FJ, Sartore-Bianchi A, Cassingena A, Siena S, et al: Epigenetic inactivation of the BRCA1 interactor SRBC and resistance to oxaliplatin in colorectal cancer. J Natl Cancer Inst 106: djt322, 2014.

18. Martinez-Balibrea E, Martínez-Cardús A, Ginés A, Ruiz de Porras V, Moutinho C, Layos L, Manzano JL, Bugés C, Bystrup S, Esteller M, et al: Tumor-related molecular mechanisms of oxaliplatin resistance. Mol Cancer Ther 14: 1767-1776, 2015.

19. Lin X, Stenvang J, Rasmussen MH, Zhu S, Jensen NF, Tarpgaard LS, Yang G, Belling K, Andersen CL, Li J, et al: The potential role of Alu Y in the development of resistance to SN38 (Irinotecan) or oxaliplatin in colorectal cancer. BMC Genomics 16: 404, 2015

20. Ginés A, Bystrup S, Ruiz de Porras V, Guardia C, Musulén E, Martínez-Cardús A, Manzano JL, Layos L, Abad A and Martínez-Balibrea E: PKM2 subcellular localization is involved in oxaliplatin resistance acquisition in HT29 human colorectal cancer cell lines. PLoS One 10: e0123830, 2015.

21. Fukuoka M, Yano S, Giaccone G, Tamura T, Nakagawa K, Douillard JY, Nishiwaki Y, Vansteenkiste J, Kudoh S, Rischin D, et al: Multi-institutional randomized phase II trial of gefitinib for previously treated patients with advanced non-small-cell lung cancer (The IDEAL 1 Trial) [corrected]. J Clin Oncol 21: 2237-2246, 2003.

22. Jackman D, Pao W, Riely GJ, Engelman JA, Kris MG, Jänne PA, Lynch T, Johnson BE and Miller VA: Clinical definition of acquired resistance to epidermal growth factor receptor tyrosine kinase inhibitors in non-small-cell lung cancer. J Clin Oncol 28 : 357-360, 2010

23. Zhang Y, Yao K, Shi C, Jiang Y, Liu K, Zhao S, Chen H, Reddy K, Zhang C, Chang X, et al: 244-MPT overcomes gefitinib resistance in non-small cell lung cancer cells. Oncotarget 6: 44274-44288, 2015.

24. Liu W, Ning J,Li C, Hu J, Meng Q, Lu H and Cai L: Overexpression of Sphk 2 is associated with gefitinib resistance in non-small cell lung cancer. Tumour Biol 37: 6331-6336, 2016.

25. Chen KL, Lin CC, Cho YT, Yang CW, Sheen YS, Tsai HE and Chu CY: Comparison of skin toxic effects associated with gefitinib, erlotinib, or afatinib treatment for non-small cell lung cancer. JAMA Dermatol 152: 340-342, 2016

26. Xue C, Hong S, Li N, Feng W, Jia J, Peng J, Lin D, Cao X, Wang S, Zhang W, et al: Randomized, multicenter study of gefitinib dose-escalation in advanced non-small-cell lung cancer patients achieved stable disease after one-month gefitinib treatment. Sci Rep 5: 10648, 2015

27. Fisher GA, Kuo T, Ramsey M, Schwartz E, Rouse RV, Cho CD Halsey J and Sikic BI: A phase II study of gefitinib, 5-fluorouracil, leucovorin, and oxaliplatin in previously untreated patients with metastatic colorectal cancer. Clin Cancer Res 14: 7074-7079, 2008.

28. Li N, Ou W, Ye X, Sun HB, Zhang L, Fang Q, Zhang SL, Wang BX and Wang SY: Pemetrexed-carboplatin adjuvant chemotherapy with or without gefitinib in resected stage IIIA-N2 non-small cell lung cancer harbouring EGFR mutations: A randomized, phase II study. Ann Surg Oncol 21: 2091-2096, 2014.

29. Ji J, Tong XH, Zhang XY, Gao Q, Li BB and Wu XX: Gefitinib inhibits the growth and induces the apoptosis of mouse I-10 Leydig testicular cancer cells in vitro. Zhonghua Nan Ke Xue 21: 797-802, 2015 (In Chinese).

30. Goldberg GS, Bechberger JF and Naus CC: A pre-loading method of evaluating gap junctional communication by fluorescent dye transfer. Biotechniques 18: 490-497, 1995.

31. Chevallier D, Carette D, Segretain D, Gilleron J and Pointis G: Connexin 43 a check-point component of cell proliferation implicated in a wide range of human testis diseases. Cell Mol Life Sci 70: 1207-1220, 2013.

32. Todd RC and Lippard SJ: Inhibition of transcription by platinum antitumor compounds. Metallomics 1: 280-291, 2009.

33. Hato SV, Khong A, de Vries IJ and Lesterhuis WJ: Molecular pathways: The immunogenic effects of platinum-based chemotherapeutics. Clin Cancer Res 20: 2831-2837, 2014.

34. Shi Y, Han Y, Xie F, Wang A, Feng X, Li N, Guo H and Chen D: ASPP2 enhances oxaliplatin (L-OHP)-induced colorectal cancer cell apoptosis in a p53-independent manner by inhibiting cell autophagy. J Cell Mol Med 19: 535-543, 2015.
35. Timme CR, Gruidl M and Yeatman TJ: Gamma-secretase inhibition attenuates oxaliplatin-induced apoptosis through increased Mcl-1 and/or Bcl-xL in human colon cancer cells. Apoptosis 18: $1163-1174,2013$

36. Shan B, Ma F, Wang M and Xu X: Down-regulating receptor interacting protein kinase 1 (RIP1) promotes oxaliplatin-induced Tca8113 cell apoptosis. Med Sci Monit 21: 3089-3094, 2015.

37. Mansure JJ, Nassim R, Chevalier S, Szymanski K, Rocha J, Aldousari S and Kassouf W: A novel mechanism of PPAR gamma induction via EGFR signalling constitutes rational for combination therapy in bladder cancer. PLoS One 8: e55997, 2013.

38. Li J, Zhu S, Kozono D, Ng K, Futalan D, Shen Y, Akers JC, Steed T, Kushwaha D, Schlabach M, et al: Genome-wide shRNA screen revealed integrated mitogenic signaling between dopamine receptor D2 (DRD2) and epidermal growth factor receptor (EGFR) in glioblastoma. Oncotarget 5: 882-893, 2014.

39. Herbst RS, Fukuoka M and Baselga J: Gefitinib - a novel targeted approach to treating cancer. Nat Rev Cancer 4: 956-965, 2004.

40. Chang GC, Yu CT, Tsai CH, Tsai JR, Chen JC, Wu CC, Wu WJ and Hsu SL: An epidermal growth factor inhibitor, Gefitinib, induces apoptosis through a p53-dependent upregulation of pro-apoptotic molecules and downregulation of anti-apoptotic molecules in human lung adenocarcinoma A549 cells. Eur J Pharmacol 600: 37-44, 2008

41. Long L, Wang J, Lu X, Xu Y, Zheng S, Luo C and Li Y: Protective effects of scutellarin on type II diabetes mellitus-induced testicular damages related to reactive oxygen species/Bcl-2/Bax and reactive oxygen species/microcirculation/staving pathway in diabetic rat. J Diabetes Res 2015: 252530, 2015.

42. Swanton E, Savory P, Cosulich S, Clarke P and Woodman P: Bcl-2 regulates a caspase-3/caspase-2 apoptotic cascade in cytosolic extracts. Oncogene 18: 1781-1787, 1999.

43. Mesnil M, Piccoli C, Tiraby G, Willecke K and Yamasaki H: Bystander killing of cancer cells by herpes simplex virus thymidine kinase gene is mediated by connexins. Proc Natl Acad Sci USA 93: 1831-1835, 1996

44. Vrionis FD, Wu JK, Qi P, Waltzman M, Cherington V and Spray DC: The bystander effect exerted by tumor cells expressing the herpes simplex virus thymidine kinase (HSVtk) gene is dependent on connexin expression and cell communication via gap junctions. Gene Ther 4: 577-585, 1997.

45. Jensen R and Glazer PM: Cell-interdependent cisplatin killing by $\mathrm{Ku} / \mathrm{DNA}-d e p e n d e n t$ protein kinase signaling transduced through gap junctions. Proc Natl Acad Sci USA 101: 6134-6139, 2004.

46. He B, Tong X, Wang L, Wang Q, Ye H, Liu B, Hong X, Tao L and Harris AL: Tramadol and flurbiprofen depress the cytotoxicity of cisplatin via their effects on gap junctions. Clin Cancer Res 15: 5803-5810, 2009

47. Eugenin EA and Berman JW: Cytochrome $c$ dysregulation induced by HIV infection of astrocytes results in bystander apoptosis of uninfected astrocytes by an $\mathrm{IP}_{3}$ and calcium-dependent mechanism. J Neurochem 127: 644-651, 2013.

48. Decrock E, Krysko DV, Vinken M, Kaczmarek A, Crispino G, Bol M, Wang N, De Bock M, De Vuyst E, Naus CC, et al: Transfer of $\mathrm{IP}_{3}$ through gap junctions is critical, but not sufficient, for the spread of apoptosis. Cell Death Differ 19: 947-957, 2012.

49. Postma FR, Hengeveld T, Alblas J, Giepmans BN, Zondag GC, Jalink K and Moolenaar WH: Acute loss of cell-cell communication caused by $\mathrm{G}$ protein-coupled receptors: A critical role for c-Src. J Cell Biol 140: 1199-1209, 1998.

50. Sorgen PL, Duffy HS, Sahoo P, Coombs W, Delmar M and Spray DC: Structural changes in the carboxyl terminus of the gap junction protein connexin 43 indicates signaling between binding domains for c-Src and zonula occludens-1. J Biol Chem 279: 54695-54701, 2004

51. Pahujaa M, Anikin M and Goldberg GS: Phosphorylation of connexin43 induced by Src: Regulation of gap junctional communication between transformed cells. Exp Cell Res 313: 4083-4090, 2007.

52. Johnstone SR, Billaud M, Lohman AW, Taddeo EP and Isakson BE: Posttranslational modifications in connexins and pannexins. J Membr Biol 245: 319-332, 2012.

53. Lampe PD, TenBroek EM, Burt JM, Kurata WE, Johnson RG and Lau AF: Phosphorylation of connexin 43 on serine 368 by protein kinase $\mathrm{C}$ regulates gap junctional communication. J Cell Biol 149: 1503-1512, 2000. 